\title{
Teacher's Motivation Techniques as Determinants of Students' Academic Performance in English Language in Selected Government Secondary Schools in Oyo State
}

\author{
Dairo Comfort Olufunmilayo \\ Department of Language Education, College of Education and Social Sciences, Legacy University, Banjul, The Gambia
}

Email address:

comfortdairo@gmail.com

\section{To cite this article:}

Dairo Comfort Olufunmilayo. Teacher's Motivation Techniques as Determinants of Students' Academic Performance in English Language in Selected Government Secondary Schools in Oyo State. International Journal of Secondary Education. Vol. 8, No. 2, 2020, pp. 36-46. doi: $10.11648 /$ j.ijsedu. 20200802.13

Received: January 20, 2020; Accepted: April 2, 2020; Published: May 28, 2020

\begin{abstract}
Motivation is a critical component in the teaching/learning process. Existing studies have examined teacher-related variables in several fields of learning but with little attention paid to teacher's motivation technique in English language teaching/learning processes of senior secondary students in Ona-Ara Local Government Area of Oyo State, Nigeria. Therefore, this study examined teacher's motivation techniques as determinants of students' performance in English Language in selected Government Secondary Schools in Ona-Ara Local Government. The sample comprised 12 English language teachers and 100 students in senior secondary school two. The research design was survey and the instruments were self-designed questionnaires and teachers' test. Percentage and frequency counts were used for the data analysis. The results revealed that teachers are aware of teacher's motivation student's academic performance. Also, most of the teachers provided motivational materials when affordable; so there was no adequate provision of the materials. The result also showed that teachers perceived motivation to be most effective technique for teaching and learning in English language classroom. Recommendations were made that the state and federal governments should organize in-service courses and workshops to improve teachers' motivation techniques to assist their students for English language teachers. There is need to restructure school's timetable to include periods of independent learning.
\end{abstract}

Keywords: Motivation, Motivation Techniques, Performance, Teaching, Learning

\section{Introduction}

The primary objective of the school is to work towards the attainment of academic excellence by the students. Although, there may be other peripheral objectives, emphasis is always placed on students' performance and sound scholarship. The extent to which these goals can be actualized depends principally, if not entirely on the school personnel, particularly the teachers. Language is a means of or vehicle of communication and, to Homo-Sapiens, it can be in form of speech of written symbol [33]. It is the meeting point of curriculum and communication. Language is necessary for thinking, structuring, shaping, and organizing experiences as well as in communicating whatever is thought, felt and organized to others [40].

Since language is so vital to learning, motivation and perception in the language classroom would consequently facilitate or enhance its learning. English is the official language as well as the "lingua franca" in Nigeria and it is very central to Nigeria educational system, since it is for now, the medium of instruction and the language of textbooks. Also, it is through the vehicle of English language that student access knowledge even in other subject areas. However, both the spoken and written aspects of English language have been a perennial problem to secondary school students in Nigeria [81]. Most students do not possess the linguistic vehicle to assimilate information or even the educational instructions delivered by the teachers. The obvious outcome is that the failure rate has remained consistently high. Several efforts to improve the low performance in English language among secondary school students and the consequent underachievement, even in other school subjects have provoked much interest and research efforts to investigate the factors that might influence the 
academic outcome of students at the secondary school level in Nigeria. These researches have been centred on collecting and reporting information about student's performance and educational condition in schools [65]. The performance of the students in English language at public examinations has also been used to measure the level of effectiveness and quality of schools in Ona-Ara Local Government of Oyo State [26].

It is not uncommon to hear comments that teachers are not as good or committed as they used to be. In diagnosing educational problems, most especially failure, reference is often made first to the teacher as causative agent. Teachers are indeed a critical factor in the actualization of school goals. Available literature points to the positive impacts of teacher's classroom practices and behaviours on student's academic performance. The need to motivate students is an important factor in student's academic performance. Aremu stressed that the issue of motivating learners is seen as an important aspect of effective learning [9]. In fact, psychologists believe that motivation is a necessary ingredient for learning because satisfactory school learning is unlikely to take place in the absence of sufficient motivation to learn.

According to Akinboye, motivation is a very important factor in school learning because it is often described as tie drive to action [1]. Hence, school psychologist's (Guidance and Counselling personnel) and many educators are often very particular about the motivating factors in school learning. Hall and Biehler and Snowman believed that there is need to motivate students so as to arouse their interest to learn [44, 15]. The behaviourists proposed reinforcing desired behaviour by using praise and rewards as extrinsic form of motivation, while the humanistic view of motivation proposed that human needs be arranged in hierarchical order. The implication here is that teachers can encourage students to meet their growth needs by enhancing the attractiveness of learning situations likely to be beneficial and minimizing dangers of possible failure [9]. It is necessary to understand the fact that there are other variables such as individual differences, motivational orientation, and self-concept among others that teachers should take into consideration. Of all the personal variables that have attracted researchers in this area of educational achievement; self-concept seems to be gaining more popularity [3].

In order word, the learner's self-worth, perception of self and the interpretation of other people's perception of him have been found to affect the learning of the child in school setting. This is probably the learner's feelings of adequacy; his expectancy levels and aspiration level in learning are largely determined by a positive self-worth $[1,64]$.

Therefore, it is important to note that teacher's motivation in the classroom can influence the student's academic performance in English language, as his method of rating the student's work, his social patterns, can predict the student's self-esteem, while the student's performance in the subject can influence the student's self-concept relating to that giving subject. This is because relationships with teachers contribute to student's satisfaction and performance in English language class. Therefore, it is logical to look at attachment in the classroom to produce varying academic outcomes. Consequently, attachment and teacher relationship in the classroom may together explain students perceived an actual academic problem, as insecure students may be overly sensitive to interpersonal difficulties, neglecting their interactions with the teacher and their English language learning.

\section{Statement of the Problem}

English language is a core subject in the school curriculum in Nigeria. The rampant failure in the subject has become so alarming. In order to arrest the current trend, there is a need for attitudinal and methodological changes as exemplified by identification and application of motivation techniques in the English language classroom. It is against this background that this study sets out to determine the relationship between selected teachers' motivational factors and student's academic performance in English language in selected secondary schools in Ona-Ara Local Government Area in Oyo State.

\section{Research Questions}

Based on the stated problem, the study would provide answers to the following research questions:

1. Are English language teachers aware of motivation as one of the determinant factors of student's academic performance in English language?

2. To what extent do teachers apply the motivation techniques in English language classroom?

3. What are the impacts of teacher's motivation on student's academic performance in English language?

\section{Theoretical Framework}

B. F. Skinner's theory of Operant Conditioning under stimulus-response considers motivation as the impact of reinforcement [11]. Skinner and his colleagues, therefore, explain motivation by determine why some experience seems to arouse respondents more than others [12, 14, 15, 44]. Reinforcement leads to association between stimuli and responses [13]. Based on Skinner's experiment with pigeons and rats, he conceived that there are psychological drives which motivate the behaviour and serve as the base for other motives [13]. A learner could be motivated in order to earn a praise, like "You have done well boy" from the teacher. Teacher who favour operant conditioning approaches must make sure that the psychological drives of the student be satisfied. Teacher can reinforce students for correct answer by using material reinforcers (prize books, pens) and nonmaterial reinforcers (prize, put on shoulder). Teacher should use reinforcers to encourage students to learn, and they should be supplied at the appropriate moment.

Also, Freud opined that behaviour is governed to a large very extent by instinct. These individual drives motivate people to seek gratification for bodily processes which help 
them to maintain equilibrium. Freud believed that our biological needs can be gratified (satisfied) through many objects. Psychoanalyst theory asserts that the mind is composed of three parts: id, the ego, and the superego; each with different functions. Freud and other psychologists explained that the conflict people experienced originates when three systems governing the mind compete with each other [74, 41],[60].

Under Maslow's Need Theory of Motivation, Maslow explained that man is constantly preoccupied with need that must be met [56]. As a result, he is predominantly directing his energy towards satisfying these needs. As each need is met, another new need arise. Abraham Maslow further posited that human needs are hierarchical and they are in two sets: the deficiency or primary needs and the growth or secondary needs. Maslow believes that deficiency needs must be satisfied before the growth needs can be met. In the same manner, a person cannot begin to approach satisfaction needs until he feels personally well-fed, safe, and loved $[55,56]$.

Also, cognitive theory believes that individuals are motivated to learn basically because they want to learn, although external reinforcement may help, it is individual's own interests, plan and desire to succeed that nourish and sustain his actions [5]. This cognitive theory emphasizes that human behaviour is influenced by the way individuals think and perceive things. On the premises of the above theories, this study examined teachers' motivation techniques as determinants of students' performance in English language in Ona-Ara Local Government Area of Oyo State.

\subsection{Teacher's Influence on Academic Performance of Students}

According to Oxford, more motivated students tended to use more strategies than less motivated students, and the particular reason for studying the language (motivational orientation, especially as related to career field) was important in the choice of strategies [66]. Endya B. Stewart stressed four important areas, which have been identified as being especially influential to secondary school student academic performance: School structural characteristics, Student effort, Peer associations, and Parental involvement [35].

According to Dryfoos, the school must become a collaborative part of the broader, community system in order to educate and enhance equality for diverse youths [31]. Of course school environment where teachers play vital roles affect academic development of students [36, 38]. The transition from elementary school to middle high school can be a scary one for youth especially when they are going from a small elementary school to larger middle school. The greater the environment changes the more difficulties that are encountered by the students [22]. Fortunately within four months, effects of school change diminish, and at that point, student difficulties are related to change by the end of their first year in middle school, parents and teachers should be working together to evaluate and support the student. Animashaun opined that an individual will only manifest his creative potentials when the environment is suitable and enabling [8].

Teachers play a vital part in the way these adolescent students feel about themselves and in how that adjust to their new environment. Compared to elementary school teachers, secondary school teachers tend to be more sceptical of youth "real" concern for their progress. Students often list the positive effects from small class and teachers who engaged them in the subject they were studying [43]. As Elman states, "Teachers do make a difference", it is imperative to understand the fact that motivation plays the role of a facilitator or catalyst in the talent development process [34]. In brief, the relationship between motivation and performance is more direct. Surprisingly, very few studies can be found in the education literature that addresses the question of independent addictive contributions of these two major determinants of academic performance. If the information is scarce in education, it appears much more abundant in the field of personnel psychology.

\subsection{Motivation and Learning}

Psychologists asserted that there is need to motivate pupils so as to arouse and sustain their interest in learning. Based on this, different schools of thought proposed ways by which pupils could be motivated to learn $[44,15]$. The behaviourists propose the reinforcing of the desired behaviour, using praise and rewards as extrinsic forms of motivation. There is caution however and that is reinforcement practices, though effective at most times tend to cause learning to be viewed as a means to an end. Furthermore, the earning of rewards and excessive of rewards may lead to resentment, limit transfer and cause dependency [78]. On the other hand, humanistic view of motivation however, proposed that human needs be arranged in hierarchical order, while the cognitivists stress that individuals are motivated when they experience a desire to find information or solution (this is intrinsic form of motivation in which learning occurs for its own sake) [57]. The snag here is that, it may be difficult to arouse a cognitive disequilibrium (or a desire to find out) in all or even most students.

According to Maslow 1968, cited in Biehlar and Snowman, the main protagonist of the view, expresses that there are two groups of needs; for instance deficiency needs and growth needs and when the deficiency needs are met, pupils are more likely to function at the high levels (that is growth needs level) [7, 15]. This means that when the deficiency needs are met, self-directed learning or the desire to know and understand, which is one of the levels of growth needs, would engage in more easily. The implication here is that teachers can encourage pupils to meet their growth needs by enhancing the attractiveness of learning situations likely to be beneficial and minimizing dangers of possible failure. From these views, Aremu identified some of the suggestions that can bring out ways of motivating students to learn as:

1) Making every subject interesting;

2) Enhancing learners' feeling of self-esteem by arranging varieties of learning experiences; 
3) Individual differences in ability, background and attitude must be taking into consideration which according to Biehlar and Snowman try to send your student away from instruction anxious to use what they have been taught and eager to learn more by associating subjects with "liked", and admired situations, things or individuals and also arranging conditions so that students feel comfortable when in the presence of a subject $[9,15]$.

All these suggestions must however be transformed into actual practice within the framework of the school curriculum. Akinboye explained that motivation affects learning at least three ways. First, as prompts or stimulus discrimination for learning because it has been observed that such effort is neither the role nor is it the deal. Also, motivation triggers behaviour sequences in the learner when it is present [1]. Since learning is said to be reacting, the learner so activated is warmed up for an easier take-off (has attained learning readiness) when compared to the person not so triggered off. Lastly, it is said to lower the threshold of reinforcements, so that reinforcement can easily be contingent on learning. This sequence of events leads more easily to increase probability of learning behaviour. However, the more creative and innovative a person is, the more selfreliant he becomes to enrich the quality of his own life and the community at large. That is to say that someone who is creative is believed to handle problems without much stress [2].

Furthermore, student's motivation to learn involves taking academic work seriously, trying to get the most form of it and apply appropriate learning strategies in the process. The social learning view suggests that, motivation to reach a goal is the product of our expectation for success and the value of the goal to us. Anderman posited that the teacher may sometimes give prizes to the best pupils in the class. Such prizes will encourage other pupils to work harder. According to Anderman and Maehr, students may not be yet experts as setting their own goals or keeping the goals in mind, so encouragement and accurate feedback are necessary $[7,53]$. Encouragement is used however to motivate learners to learn. Such an encouragement may be more effective if the learner hopes to gain something after learning the task. Such things as rewards, incentive system or praises like "fine", "ok", "well done", "that's fine", to mention but few.

According to Carolyn and Joan, achievement motivation theory involves two different approach goals that people tend to adopt while engaged in achievement tasks that influence thoughts, affect and behaviour [19, 6] [5, 29, 30, 63, 47]. Some students are motivationally oriented towards one type goal, mastery goals, task involvement; others are oriented towards learning and performance goals [29, 5, 63, 29, 30, $32,10,67]$. Effort can become a double-edged when trying hard, does not lead to success [23, 24, 25]. Students with learning goals see the purpose of schooling as gaining competence in the skills being taught, whereas students with performance goals primarily seek to gain positive judgments of their competence (and avoid negative judgment), ability goal or ego involvement, seek to demonstrate superior competence at the task $[46,5,29,61,63,54,46]$. Students who are striving towards learning goals are likely to take difficult courses and seek challenges; students with performance goals focus on getting good grades, take easy courses and avoid challenging situations [27, 28].

In, another vein, students with learning goals and those with performance goals do not differ in overall intelligent, but their classroom performance-oriented tend to become discouraged, and their performance is seriously hampered. In contrast, when learning-oriented students encountered obstacles, they tend to keep-trying and their motivation and performance may actually increase [53, 29, 71, 72, 73]. Learning-oriented students are more likely to use metacognitive or self-regulated learning strategies [67]. Performance-oriented students who perceive their abilities to be low are likely to fall into a pattern of hopelessness, for they believe that they have little chance of earning good grades. Learning-oriented students who perceive their abilities to be low do not feel this way; they are concerned with how much they themselves can learn, without regard for the performance of others [42, 51, 80]. Unfortunately, there is evidence that over their years in school, students tend to shift from learning or mastery goals to performance goals [58]. Brophy cited in Ames, described "motivation to learn" as where the goal is to master new skills or content is compatible with a mastery goal [17]. According to Canter, when a student has the confidence and belief in venturing and completing a task, and coping with the ever changing environment, he can boast of bright performance and attainment of life goals [18]. As posited by Richard and Edward, there are three motivational states - intrinsic motivation, extrinsic motivation and amotivation [68]. They explained that intrinsic motivation remains an important construct, reflecting the natural human propensity to learn and assimilate; extrinsic motivation is argued to vary considerably in its relative autonomy and thus can either reflect external control or true self-regulation, while amotivation is unwillingness to engage in a particular task or behaviour.

\subsection{Methods of Rewarding Students' Performance}

(Richard and Edward; Shabeena et al; Joyce and William, depicted the types of motivation as intrinsic and extrinsic and their contribution to teaching and learning situation $[68,70,50]$. According to Joyce and William, intrinsic motivation is the satisfaction of a desire, expectation, or goal without being influenced to do so by another person or by an external incentives or reward; while extrinsic motivation is a compel to do something or act a way because of external factors [50]. These factors can include incentives or rewards or even punishments. The goals or expectations of this type of motivation may be determined by someone else. It is sometimes called self-motivation. It is significant to understand that incentive systems are used in classroom to focus students' efforts and not ability. A common way to spur students to put in effort is to reward effort directly by praising students for such efforts as is done in many schools. Other methods include:

\subsubsection{Using Praise Effectively}

Praise serves many purposes in classroom instruction but 
is primarily used to reinforce appropriate behaviours and give feedback to students what they are doing right. Overall, it is a good idea to use praise frequently especially with young children and in classroom with many low performing students 16, 39]. However, what is more important than the amount of praise is the way it is giving, [62]. Praise should be given for right answers and appropriate behaviours. Teacher needs to praise students for specific behaviour, not for general "goodness". Brophy notds that when praise low achievement or disruptive students for good work, teachers often contradict their words with tone, posture or other nonverbal cue [16]. This emphasises that praise should be given for good performance relative to a student's usual level of performance [59].

\subsubsection{Teaching Students to Praise Themselves}

There is increasing evidence that students can learn to praise themselves and this increases their academic success. For example, children can learn to mentally give themselves a pat on the back when they finish a task or to stop at a regular interval to notice how much they have done [21, 69]. This strategy is a key component of self-regulated learning.

\subsubsection{Using Grades as Incentives}

Many scholars show their view about using grades as incentives; comparing graded and ungraded college classes the experiment shows substantially higher performance in the graded classes. Grades work as incentives in part because the increase the value of other rewards given closer in time to the behaviour they reinforce. However, the grading system used by most schools serves three different functions at the same time; evaluation, feedback and incentive. This function makes grades less than ideal for each function, because they are based largely on ability rather than on effort, they are less than ideal for motivating students to exert, maximum efforts as was noted earlier. Also, grades are given too in frequently to be very useful as either feedback or incentives for young children who cannot see the connection between today's work and a grade to be received in the next four weeks. Grades are effective as incentives for older students [45].

\subsubsection{Individual Learning Expectation}

Slavins and Stevens et al, developed and evaluated a method of rewarding students for improvement called Individual Learning Expectations (ILE). Another way to provide incentives to learn is to recognize students' improvement over their own past record [75, 76, 79]. The advantage of improvement score is that it is quantified and does not rely as heavily on teachers' subjective judgement as an effort judgment does. All but the highest-performing students are capable of improvement and highest-performing students can be rewarded for perfect papers, which will be will within their reach.

\subsubsection{Incentive Systems Based on Goal Structure}

One of classroom incentive systems that received considerable research attention in recent years is the goal structure of the classroom. This term refers to the degree to which students are in cooperation or competition with one and another. If students are in competition, any student's success means another's failure [49].

\subsubsection{Competitive Goal Structure}

Competitive goal structures have been criticized for discouraging students from helping one another to learn, for tending to set up a breaking order in the classroom and for establishing a situation in which low achievers have little chance of success [48, 4, 77]. Coleman noted that an individual student's in sport is strongly supported by other students because the sport hero brings glory to the team and the school, but those students encourage one another's academic achievements because in the competitive academic system, achievement brings success only to the individual $[21,25]$.

The basic points stressed in the reviewed literature are the specific goals derived from the use of motivation skills in the teaching and learning of English language for student's academic performance or achievements. The reviewed literature reveals that suitable motivation techniques are facilitators of teaching/learning and that when applied appropriately, and in rich variety and range can help to achieve curriculum objectives. Furthermore, the general aim of using motivation techniques was to make the teaching/learning of English language more meaningful through appraisal, reinforcement and incentives when used to provide students with the opportunity to exercise their thinking faculty and this is the focus of this study.

\section{Research Design}

Survey research design was used for this study. This because the variables are not manipulated; they already exist.

\subsection{Research Population and Sampling}

The population of the study comprised all English language teachers and SS2 students from senior secondary schools in Ona-Ara Local Government Area of Oyo State. Random sampling procedure was used to select 12 English language teachers and 100 senior secondary school 2 students from five randomly selected schools in Ona-Ara Local Government Area of Oyo State.

\subsection{Research Instruments}

The instruments used were a set of four point Likert scale questionnaires which consisted of 16 items for the English language teachers and 12 items for the SS2 students. An achievement test in English language was also administered to the students. The test was validated with test-retest procedure using a group of students that are separate from the participants in this study. The questionnaires were validated using Cronbach Alpha statistics with reliability coefficient of 0.69 and 0.74 respectively.

\section{Method of Data Analysis}

Data collected were analysed using percentage and 
frequency counts to answer the research questions generated for this study.

\subsection{Discussion and Analysis of Findings}

\subsubsection{General Information About Teachers}

Table 1. Teachers' names and their working experience.

\begin{tabular}{|c|c|c|c|c|c|c|c|c|c|c|c|c|c|}
\hline \multirow[b]{2}{*}{ Name of schools } & \multirow{2}{*}{$\begin{array}{l}\text { No } \\
\text { Trs }\end{array}$} & \multirow[b]{2}{*}{ Male } & \multirow{2}{*}{$\begin{array}{l}\% \text { of } \\
\text { Male }\end{array}$} & \multirow[b]{2}{*}{ Female } & \multirow{2}{*}{$\begin{array}{l}\% \text { of } \\
\text { Female }\end{array}$} & \multirow[b]{2}{*}{ Graduates } & \multirow{2}{*}{$\begin{array}{l}\% \text { of } \\
\text { Graduates }\end{array}$} & \multirow{2}{*}{$\begin{array}{l}\text { Non- } \\
\text { graduates }\end{array}$} & \multirow{2}{*}{$\begin{array}{l}\% \text { of Non- } \\
\text { Graduates }\end{array}$} & \multicolumn{4}{|c|}{ Experience } \\
\hline & & & & & & & & & & $\begin{array}{l}\text { Old } \\
\text { Trs } \\
\end{array}$ & $\begin{array}{l}\% \text { of Old } \\
\text { Trs }\end{array}$ & $\begin{array}{l}\text { New } \\
\text { Trs } \\
\end{array}$ & $\begin{array}{l}\% \text { of } \\
\text { New Trs }\end{array}$ \\
\hline $\begin{array}{l}\text { Zummuratul Hujaj Gram. } \\
\text { Sch., Olorunsogo }\end{array}$ & 02 & 02 & 100 & - & - & 01 & 50 & 01 & 50 & 02 & 100 & 00 & 00 \\
\hline $\begin{array}{l}\text { Elekuro High Sch., Oke- } \\
\text { Ogbere }\end{array}$ & 03 & 01 & 33 & 02 & 67 & 02 & 67 & 01 & 33 & 02 & 67 & 01 & 33 \\
\hline $\begin{array}{l}\text { Elekuro High Sch., Oke- } \\
\text { Ogbere }\end{array}$ & 03 & 01 & 33 & 02 & 67 & 02 & 67 & 01 & 33 & 02 & 67 & 01 & 33 \\
\hline $\begin{array}{l}\text { Anglican Gram Sch., } \\
\text { Ojebode }\end{array}$ & 01 & 01 & 100 & 00 & 00 & 00 & 00 & 01 & 100 & 01 & 100 & 00 & 00 \\
\hline $\begin{array}{l}\text { Community Grammar } \\
\text { Sch., Akanran }\end{array}$ & 01 & 01 & 100 & 00 & 00 & 01 & 100 & 00 & 00 & 01 & 100 & 00 & 00 \\
\hline Total & 12 & 07 & 58 & 05 & 42 & 08 & 67 & 04 & 33 & 10 & 83 & 02 & 17 \\
\hline
\end{tabular}

Table 2. Class taught.

\begin{tabular}{lllll}
\hline & JSS & \% JSS & SSS & \% SSS \\
\hline 1 & 03 & 50 & O3 & 50 \\
2 & 03 & 33 & 03 & 67 \\
3 & 06 & 40 & 09 & 60 \\
4 & 03 & 50 & 03 & 50 \\
5 & 03 & 50 & 03 & 50 \\
Total & 18 & $55 \%$ & 14 & $45 \%$ \\
\hline
\end{tabular}

Table 3. Educational programmes attended by English language teachers.

\begin{tabular}{lll}
\hline Educational programmes & No. of teachers & \% of teachers \\
\hline In-service training & 02 & 17 \\
Conference (s) & 01 & 08 \\
Seminars & 10 & 83 \\
Workshops & 09 & 75 \\
\hline
\end{tabular}

\subsubsection{Discussion on Findings}

Tables 1 and 2 above show the general information, the sex, qualification (s), experience in year (s), and class (es) taught: while table 3 shows the various educational programmes attended by the teachers at one time or the other.

\subsection{Discussion of Findings Based on Research Questions}

The analysis was done using the instrument based on the research questions one-one match.

\subsubsection{Teacher's Level of Awareness of Influence of Teacher's Motivation on Student's Academic Performance}

Research question 1: Are the English language teachers aware of influence of teacher's motivation on student's academic performance?

Table 4. Number of teachers and their level of awareness.

\begin{tabular}{lllll}
\hline $\begin{array}{l}\text { Number of } \\
\text { teachers }\end{array}$ & Aware & Not aware \\
\cline { 2 - 5 } & No. of Trs & $\%$ of Trs & No. of Trs & \% of Trs \\
\hline 12 & 10 & 83 & 02 & 17 \\
\hline
\end{tabular}

Table 4 above shows the level of awareness of teachers on the influence of teacher's motivation. Result shows that teachers were aware of the teacher's motivation on student's academic performance. The table reveals that $10(83 \%)$ teachers were aware of the influence of teacher's motivation on student's academic performance in English language. Respondents said they were aware of the motivation techniques. Actual observation shows that most of the teachers do apply motivation techniques in their various English classrooms.

\subsubsection{Perception of Teachers on the Roles of Applying Acquired Motivation Techniques}

Research question 2: To what extent do teachers apply acquired motivation techniques?

Table 5. Motivation techniques and the extent of their application.

\begin{tabular}{llll}
\hline & Motivation techniques & No of Teachers and the\% of the extent of application of the techniques & Often \\
\hline & & Always & \\
\hline 1 & Praise & \\
2 & Incentives or reward & \\
3 & Competition & \\
4 & Counselling & \\
5 & Availability of materials and interesting apparatus & \\
6 & Punishment & \\
7 & Previous knowledge & \\
8 & Grading & \\
\hline
\end{tabular}




\begin{tabular}{|c|c|c|c|c|c|c|}
\hline & \multirow[t]{2}{*}{ Motivation techniques } & \multicolumn{5}{|c|}{ No of Teachers and the\% of the extent of application of the techniques } \\
\hline & & Always & Often & Occasionally & Rarely & Never \\
\hline 9 & Recommendations & $2 / 17 \%$ & $3 / 25 \%$ & $4 / 33 \%$ & $2 / 17 \%$ & $1 / 8 \%$ \\
\hline
\end{tabular}

Table 6. Teacher's responses to the application of motivation techniques.

\begin{tabular}{lllll}
\hline Motivation techniques & Teacher's responses & & Disagree \\
\hline & Agree & & No. of Trs & \% of Trs \\
\hline Motivation techniques aid teaching. & No. of Trs & \%of Trs & 02 & 17 \\
They provide the desire to learn in student (s). & 10 & 83 & 02 & 17 \\
I am encouraged to provide motivational materials. & 10 & 83 & 04 & 33 \\
Their application is a waste of time. & 08 & 67 & 17 & 83 \\
I have no time for such extra effort. & 02 & 25 & 09 & 75 \\
\hline
\end{tabular}

Table 5 reveals that teachers have a positive attitude to applying motivation techniques while teaching English language. The table shows that $3(33 \%)$ respondents did apply the motivation techniques occasionally $1(8 \%)$ of them said they never use the techniques. 2 (17) respondents said they applied them when examination were around the corner, while $3(25 \%)$ respondents used them often. 2 (17\%) respondents attested that they rarely applied motivational materials. $1(8 \%)$ respondents attested the fact that they did not have enough time for such extra effort considering the normal duration for class work.

Table 6 further reveals that $10(83 \%)$ respondents agreed that the application of motivation techniques aid teaching, while $2(17 \%)$ respondents had contrary view. While $8(67 \%)$ respondents agreed that they were encouraged to provide or improvise motivational materials, 4 (33\%) respondents said they were never encouraged to provide or improvise motivational materials, even in the face of perceiving benefit that could be derived by their application. 2 (17\%) respondents saw the use motivational techniques as a waste of time, while $3(25 \%)$ respondents viewed the use motivational techniques as extra effort. $10(83 \%)$ respondents attested the fact that their application provides the desire in the student (s) to learn.

\subsubsection{Impact of Teacher's Motivation on Student's Performance in English Language}

Research question 3: What are the impacts of teacher's motivation on student's academic performance in English language?

Table 7. Teacher's responses to awareness of teacher's impacts of teacher's motivation.

\begin{tabular}{|c|c|c|c|c|c|}
\hline \multicolumn{2}{|c|}{ Statements } & \multicolumn{4}{|c|}{ Teacher's responses } \\
\hline & & No. of Trs & $\%$ of Trs & No. of Trs & $\%$ of Trs \\
\hline 1 & Performance of my students improves when I apply motivation techniques. & 11 & 92 & 01 & 08 \\
\hline 2 & They make my lessons very interesting. & 10 & 83 & 02 & 17 \\
\hline 3 & I do not apply them because they make my work tedious. & 01 & 08 & 11 & 92 \\
\hline 4 & Motivation techniques do not improve my student's performance. & 02 & 08 & 11 & 92 \\
\hline 5 & My students complained about their application in class. & 02 & 17 & 10 & 83 \\
\hline
\end{tabular}

Table7 above shows teacher's perceptions about the impacts of teacher's motivation on student's academic performance in English language. They confirmed the positive impacts of teacher's motivation on student's academic performance in English language.

The table reveals that most of the respondents appreciated fact that application of motivation techniques improves their student's academic performance in English language, but the fact remains that not all of them apply motivation materials due to non-availability support from both the schools and the government. $11(92 \%)$ respondents agreed that the application of motivation techniques improves academic performance of their students, while 1 (8\%) respondent disagreed. $10(83 \%)$ respondents are of the opinion that the application of these techniques in English language teaching/learning makes the lessons interesting, while 2 $(17 \%)$ had a contrary opinion. $1(8 \%)$ respondent was of the view that their application makes their work tedious, while $11(92 \%)$ did not share this point of view. $1083 \%$ ) did not agree that their students complain about the use of these techniques in English language classes, while 2 (17\%) had a contrary view.

\subsection{General Information About Students and Their Perception on Teacher's Motivation}

Table 8. Schools' names and students' perception on teacher's attitude.

\begin{tabular}{|c|c|c|c|c|c|c|c|c|c|c|}
\hline \multirow[t]{2}{*}{ Name of schools } & \multirow[t]{2}{*}{$\begin{array}{l}\text { No. of SS2 } \\
\text { Students } \\
\end{array}$} & \multirow[t]{2}{*}{ Male } & \multirow[t]{2}{*}{ Female } & \multicolumn{3}{|c|}{$\begin{array}{l}\text { Application of } \\
\text { motivation techniques }\end{array}$} & \multicolumn{2}{|c|}{$\begin{array}{l}\text { Availability of } \\
\text { motivational materials }\end{array}$} & \multicolumn{2}{|c|}{$\begin{array}{l}\text { Teacher-Student } \\
\text { interaction }\end{array}$} \\
\hline & & & & All & Some & None & Yes & No & Yes & No \\
\hline Zummuratul Hujaj Gram. Sch., Olorunsogo & 1 & 08 & 10 & 01 & 17 & - & 04 & 14 & 03 & 15 \\
\hline
\end{tabular}




\begin{tabular}{|c|c|c|c|c|c|c|c|c|c|c|c|}
\hline & \multirow[t]{2}{*}{ Name of schools } & \multirow[t]{2}{*}{$\begin{array}{l}\text { No. of SS2 } \\
\text { Students } \\
\end{array}$} & \multirow[t]{2}{*}{ Male } & \multirow[t]{2}{*}{ Female } & \multicolumn{3}{|c|}{$\begin{array}{l}\text { Application of } \\
\text { motivation techniques }\end{array}$} & \multicolumn{2}{|c|}{$\begin{array}{l}\text { Availability of } \\
\text { motivational materials }\end{array}$} & \multicolumn{2}{|c|}{$\begin{array}{l}\text { Teacher-Student } \\
\text { interaction }\end{array}$} \\
\hline & & & & & All & Some & None & Yes & No & Yes & No \\
\hline 2 & Elekuro High Sch., Oke-Ogbere & 18 & 07 & 11 & 01 & 17 & - & 02 & 02 & 04 & 17 \\
\hline 3 & Elekuro High Sch., Oke-Ogbere & 18 & 15 & 03 & 01 & 17 & - & 01 & 17 & 03 & 15 \\
\hline 4 & Anglican Gram Sch., Ojebode & 20 & 12 & 08 & 02 & 18 & - & 01 & 19 & 07 & 13 \\
\hline \multirow[t]{2}{*}{5} & Community Grammar Sch., Akanran & 18 & 05 & 13 & 04 & 14 & - & 02 & 16 & 06 & 10 \\
\hline & & 92 & 47 & 55 & 10 & 83 & - & 10 & 68 & 23 & 67 \\
\hline
\end{tabular}

Table 8 shows general information about students and their perception on English language teacher's attitude towards applying motivation techniques /motivation materials to encourage student (s) for academic performance in English language classroom. Most of the student respondents agreed that their English language teachers applied motivational techniques, but they were of the view that the motivational techniques inappropriately applied.

The table shows that the relevant motivational materials such as pencils, books, erasers, badges and instructional materials were not available; and where available, they were not appropriately used in the classes. A high percentage of students' respondents have negative views about the application of motivational materials in English language classrooms. The fact of the matter, from the observation indicates that most of the listed materials were lacking or unavailable in the schools. Chalkboards and teachers' textbooks were perhaps the most readily available materials in our public secondary schools. More so, a percentage of the students revealed that they hate punishment. (This punishment, as observed, is one of the reinforcement almost of the teachers used). Furthermore, only just a few of the students have experienced teacherstudent relationship.

\section{Conclusion}

This revealed that influence of teacher's motivation on student's academic performance in English language is of paramount importance to educational development of this country. It has helped to provide clearer direction for English language teachers to enhance motivation in relation to students' academic performance in the subject. It is significant that the results of this study should inform the field about how classroom processes can affect student's motivation in association with their attitude to learn and how teachers can support their efforts to tailor instructional approaches to optimize student's motivation. All teachers can offer support and expertize to their students. It could be expected that teachers with a positive attitude to the students and the techniques to help them would be more effective, and with training would be even more so.

The academic performance of the students can be enhanced by well-acquired, executed and applied motivation techniques suitable for their needs. Wider support, especially teacher's support, is essential for students to reach the highest levels of performance. In conclusion, all English language teachers should be involved in establishing programmes and activities, since if students spend time with disinterested teachers rather than with those encouraged to motivate them, they may not be encouraged to perform well. English language teachers should be aware of their own attitudes towards the students and help them to understand why they may feel that such learners can look after themselves.

\section{Implication of the Study in English Language}

Significantly, the findings of this study have implications for encouraging students in secondary schools in Oyo State. In the first instance, there is need for English language teachers in secondary schools to identify the psychological variables such as self-esteem, scholastic and achievement motivation, locus control, ego identity and autonomy among the students because these variables relate to low academic performance of secondary school students. In other words, once these variables are identified through psychological assessment and personal counselling given with appropriate classroom intervention to students, high performance in English language will be possible. In addition, English language teachers in secondary schools should provide supportive relationship for personal interest development towards the subject. They should encourage the students to explore self and psychological environment so as to increase their self-knowledge and academic performance.

\section{Recommendations}

Based on the findings of this study, the followings are hereby recommended:

1. Firstly, both the state and federal governments should organize in-service courses and workshops aimed at improving their motivation techniques to assist their students for English language teachers.

2. Formal teaching can be loosened with willingness to alter routine. This could be done by restructuring the school's timetable to include periods of independent learning.

3. Students should be made to have contact with professionals for mentorship so as to benefit from interactions with experts such as lawyers, journalists, diplomats and others, who without attaining certain levels of performance in English language could have been limited. This could via assigning students to personal mentors. 


\section{References}

[1] Akinboye, J. O. (1996), Psychological Foundations of Education in Africa. Lagos, Stirling. Horden.

[2] Akinboye J. O. (2003), Creativity, innovation and success Ibadan: CYFO Behaviour services Ltd.

[3] Akinsola, M. K. and Tijani, R. O. (1999): The Relationship between Mathematics Self-concept and Achievement in Mathematics. Nigerian Journal of Applied Psychology 5: 1 \& 2 (260-267).

[4] Ames, C. (1984). Competitive, cooperative, and individualistic goal structures: A cognitive motivational analysis. In R. Ames \& C. Ames (Eds.): Research on motivation in Education 1: Student motivation (177-208). New York: Academic Press.

[5] Ames, C., \& Archer, J. (1988): Achievement goals in the classroom: Student learning strategies and motivation processes. Journal of Educational Psychology, 80, 260-267.

[6] Ames, C. (1992). Classrooms: Goals, structures, and student motivation. Journal of Educational Psychology, 84, 261-271.

[7] Anderman, M. K. (1993): Motivation for Achievement Possibilities for Teaching and Learning, Mahwah, NJ: Lawrence Erlbaum Associates, Inc. Publishers.

[8] Animashaun, R. A. (2002), Differential Effectiveness of Two Creativity Techniques in Enhancing Creativity Motivation of some Nigerian Adolescent Prisoners in Nigerian Journal of Applied Psychology 7: 1, (134-138).

[9] Aremu Ayotola (1998): Motivating Learners for more effective achievement in mathematics, in Nigerian Journal of Applied Psychology, 4: 1 (27-34).

[10] Baumert, J. et al (1997): TIMSS - Third International Mathematics and Science Study, (239) in Biehler, R. F. and Snowmnan, J. (1986), Psychology Applied to Teaching (5th Ed.) Boston: Houghton Mifflin Company.

[11] B. F. Skinner (1904 - 1990): Operant Conditioning. Wikipedia, the free encyclopedia. En.wiki/Operantconditioning

[12] B. F. Skinner (1938): The Behavior of organisms: An experimental analysis. New York: Appleton - Century- Crofts, p 457.

[13] B. F. Skinner (1948): Superstition in the pigeon. Journal of Experimental Psychology, 38, (168-172).

[14] B. F. Skinner (1953): Science and human behavior. https://www.simonandschuster.com/books/Science-AndHuman-Behavior/B-F-Skinner/9780029290408

[15] Biehler, R. F. and Snowmnan, J. (1986): Psychology Applied to Teaching (5th Ed.) Boston: Houghton Mifflin Company.

[16] Brophy, Jere (1981): Teacher praise: A functional analysis. Review of Educational Research, 51, (5-32).

[17] Brophy, J. (1983): Conceptualizing student motivation: Educational Psychologist, 18, (200-215).

[18] Canter, A. (2004): A Problem-Solving Model for improving Students Achievement: Principal Leadership Magazine, 5: 4, (101-107).

[19] Carolyn M. Jagacinski and Joan L. Duda (2001): A
Comparative Analysis of Contemporary Achievement Goal Orientation Measure. Journal of Educational and Psychological Measurement. Vol. 61, Issue 6. https://doi.org/10.117700131640121971626

[20] Coleman J. S. (1990): Equality and achievement in education. San Francisco: Westview Press.

[21] Corno, L. \& Kanfer R. (1993): "The role of volition in learning and performance". In Review of Research in Education, 19, (301- 341), Edited by L. Darling-Hammond. Washington, DC: American Educational Research Association.

[22] Cottrel, J. L. (1992): The relation of attachments and supports to adolescent well-being and school adjustment. Journal of Adolescent Research, 7, (28-42).

[23] Covington, M. \& Omelich. C. (1979a): Are causal attributions causal? A path analysis of the cognitive model of achievement motivation. Journal of Personality and Social Psychology. 37. (1487-150).

[24] Covington, M. \& Omelich. C. (1979b) Effort: The doubleedged sword in school achievement. Journal of Educational Psychology, 71, (169-182).

[25] Covington, M. \& Omelich. C. (1984): Task oriented versus competitive learning structures: Motivational and performance consequences. Journal of Educational Psychology, 76, (10381050).

[26] Dairo, Comfort O. (2012): Influence of Teacher's Motivation on Students' Academic Performance in English Language in some selected Government Secondary Schools in Oyo State. Unpublished Thesis, Post-Graduate Diploma in Education, National Teachers' Institute, Kaduna.

[27] Deci, E. L., Betley, J., Kahle, L., Abrams, L., \& Porac, J. (1981): When trying to win: Competition and intrinsic motivation. Personality and Social Psychology Bulletin, 7, (79-83).

[28] Deci, E. 1. and Ryan R. M. (1985): Intrinsic and selfdetermination in human behaviour. New York, Plenum.

[29] Deweck C. S. (1986): Motivational processes affecting learning. American Psychologist, 41, (1040-1048).

[30] Deweck, C. S., \& Leggett, E. (1988): A social-cognitive approach to motivation and personality. Psychological Review, 95, (256-273).

[31] Dryfoos, J. (1998): Safe passage: Making it through adolescence in a risky society: What parents, schools, and communities can do. New York: Oxford University Press.

[32] Duda, J. L. (1989): Relationship between task and ego orientation and the perceived purpose of sport among high school athletes. Journal of Sport and Exercise Psychology, 11, (318-335).

[33] Duyilemi, A. N. (2005): Language proficiency and the learning of sciences. In Dada, A et al (eds.): Issues in language, communication and education. Ibadan: Constallations Books.

[34] Elman Jeffrey L. (1991): Distributed Representations, Simple Recurrent Networks, and Grammatical Structure, Departments of Cognitive Science and Linguistics, University of California, San Diego, Machine Learning, 7, (195-225), (C) 1991 Kluwer Academic Publishers, Boston. 
[35] Endya B. Stewart (2087): The Influence of School- and Individual-Level Factors on Academic Achievement: School Structural Characteristics, Student Effort, Peer Associations, and Parental Involvement, Education and Urban Society, 40: 2, (179-189). Corwin Press Inc.

[36] Epstein, J. L. (1988): Effective schools or effective students: Dealing with diversity. In R. Haskins \& D. MacRae (Eds.), Policies for America's public schools: Teacher equity indicators. Norwood, NJ: Ablex

[37] Epstein, J. L. (1989): Family structures and student motivation: A developmental perspective. In C. Ames \& R. Ames (Eds.) Research on motivation in education: Vol. 3. Goals and cognition. Orlando: Academic Press.

[38] Epstein, J. L. (1991): Effects of student achievement on teachers' practices of parents' involvement. Advances in Reading/Language Research: Literacy through family, community and school interaction, 5, (261-276). Greenwich, CT: JAI Press

[39] Evans Gary W. (1996): Multiple stressors: Performance, Psychophysiological and affective Responses. Journal of Environmental Psychology, 16: 2, (147-154)

[40] Ezeokoli, F. O. (2005): Home language as discriminant of reading interests of Senior Secondary School Students in Oyo State, Nigeria. Issues in language, communication and education: In A. Dada, A. Abimbade and O. O. Kolawole. (Eds.) (2005). Ibadan: Department of Teacher Education. 77-97.

[41] Freud, S. (1923): The ego and the id. SE, 19: 1- 66. In McLeod, S. A. (2019, Sept 25). Id, ego and superego. Simply Psychology: https://www.simplypsychology.org/psyche.html

[42] Fuchs Doglas, Fuchs Lynn S., Mathes, P. G., \& Simmons, D. C. (1997): Peer-assisted learning strategies: Making classrooms more responsive to diversity. American Educational Research Journal, 34, (174-206).

[43] Gregory (1995): The influence of general perceptions of the training environment on pre-training motivation and perceived training transfer, Journal of Management, 21: 1, (1-25).

[44] Hall, J. F. (1989): Learning and Memory (2nd Ed.), Massachusetts: Allyn and Bacon.

[45] Ingalls, V. (2018). Incentivizing with bonus in a college statistics course. REDIMAT, 7 (1) 93 - 103. doi:https/dx.doi.org/10.17583/redimat.2018.2497

[46] Jagacinski, C. M., \& Nicholls, J. G. (1984a-b): Conceptions of ability and related affects in task involvement and ego involvement. Journal of Educational Psychology, 76, (909919).

[47] John G. Nicholls et al (1989): Individual differences in academic motivation: Perceived ability, goals, beliefs, and values. In Learning and individual differences. Vol. 1, Issue $1,1998(63 \quad$ - 84) https://doi.org/10.1016/10416080(89)90010-1

[48] Johnson, D., \& Johnson, R. (1985): Motivational processes in cooperative, competitive, and individualistic learning situations. In C. Ames \& R. Ames (Eds.): Research on motivation in education. Vol. 2: The classroom milieu, (249286). Orlando, FL: Academic Press.

[49] Johnson, D. W., \& Johnson, F. P. (1987): Joining together: Group theory and group skills (3rd Ed.)
[50] Joyce Nyam, T. o. William-West (2014). Teacher Motivation: A Study of psychology and Sociological Factors. International Journal of Education and Research. Vol. 2 No. 2, Department of Academics and Planning Danbo International School, Kaduna State, Nigeria

[51] Kaplan Avi \& Midgley Carole (1997): The effect of achievement goals: Does level of perceived academiccompetence make a difference? Contemporary Educational Psychology, 2: 4, 415-435) https://doi.org/10.1006/ceps.1997.0943

[52] Lepper Mark M., David Greene and Richard E. Nisbett (1973). "Undermining Children Intrinsic Interest With External Reward: A Test of Undermining Hypothesis" Journal of Personality and Social Psychology,(129 - 147), In Sterling, Dianna. "Teacher Motivation". Learner Development Institute. 19 March 2016. Web

[53] Maehr, M. L. (1984): Meaning and motivation: Toward a theory of personal investment. In R. Ames \& C. Ames (Eds.): Research on motivation in education, 1, (115-144). New York: Academic Press.

[54] Maehr, M. L. \& Nicholls J. G. (1980). Culture \& achievement Motivation: A Second look. In N. Warren (Eds.), Study in Cross-cultural Psychology. Vol. 2 (221 - 269)

[55] Maslow Abraham, H. (1943): A theory of human motivation, Psychological Review in Maslow's hierarchy of needs From Wikipedia, the free encyclopedia

[56] Maslow Abraham, H. (1954): Motivation and personality, New York: Harper and Row, in Maslow's hierarchy of needs From Wikipedia, the free encyclopedia https://en.wikipedia.org/wiki/Maslow\%27s_hierarchy_of_nee ds Review, 50: 4, (370-96).

[57] Maslow Abraham, H. (1968): Toward a psychology of being. Second Edition. New York: Van Nostrand Reinhold, Inc., pp 1 -8. New York

[58] Meece Judith L. (1991): The Classroom Context and Student Motivational Goals in M. L. Maehr \& P. R. Pintrich (Eds.) Advances In Motivation And Achievement 7, (261-285) Greenwich. CT: JAI Press. Google Scholar.

[59] Miller, A., \& Hom, H. (1997): Conceptions of ability and the interpretation of praise, blame, and material rewards. Journal of Experimental Education, 65, (163-177).

[60] McLeod, S. A. (2019, Sept 25). Id, ego and Superego. Simply Psychology: https://www.simplypsychology.org/psyche.html

[61] Midgley, C., Kaplan, A., Middleton, M., Maehr, M. L., Urdan, T., Anderman, L. H., Anderman, E. \& Roeser, R. (1998): The development and validation of scales assessing students' achievement goal orientations. Contemporary Educational Psychology, 23, 113-131.

[62] Nafpaktitis, M., Mayer, G., \& Butterworth, T. (1985): Natural rates of teacher approval and disapproval and their relation to student behavior in intermediate school classrooms. Journal of Educational Psychology, 77, (362-367).

[63] Nicholls, J. G. (1984). Achievement motivation: Conceptions of ability, subjective experience, task choice, and performance. Psychological Review, 91 328-346. geometry class in Contemporary educational psychology, 21: 4, (467476). 
[64] Noemi Herranz-Zarzoso, Gerardo Sabater-Grande (2018): Monetary incentives and self-chosen goals in academic performance: and experimental study. International Review of Economics Education. Vol. 27, pp. 34 - 44, LEE \& Economics Department, University Jaume I, Av. De Vicent Sos Baynat, s/n 12071, Castellón, Spain

[65] Oloyede, D. O. (2003): Resources availability, utilization and academics achievements of students in selected secondary schools in Ibadan. Ibadan, Journal of Education Studies, 3: 1$2,(40-47)$.

[66] Oxford, R. L., Park-Oh, Y., Ito, S. \& Sumrall M. (1993): Learning Japanese by satellite: What influences student achievement? "System," 21, (31-48).

[67] Pintrich, P. R., Marx, R., and Boyle, R. (1993), "Beyond cold conceptual change: the role of motivational beliefs and classroom contextual factors in the process of conceptual change," Review of Educational Research, 63: 2 (167-199).

[68] Richard, M. Ryan and Edward, L. Deci. (2000): Intrinsic and Extrinsic Motivation: Classic Definitions and New Directions. Contemporary Educational Psychology, Vol. 25, Issue 1 (54 67)

[69] Ross, J. A., Rolheiser, C., \& Hogaboam-Gray (1998): Skills training versus action research in-service: Impact on student attitudes on self-evaluation. Teaching and Teacher Education, 14: $5(463-477)$.

[70] Shabeena Shaheen et al (2013): Motivational Techniques for Effective Learning: A Meta-Analysis. Education Departmental, National University, of Modern Languages (NUML), Islamabad, Pakistan

[71] Schunk Dale, H. (1984): Self-efficiency perspective on achievement behaviour, Journal of Educational Psychology, $19,(848-857)$.

[72] Schunk Dale, H. (1989): Self efficiency and cognitive learning. In C. Ames and R. Ames, (Eds.) (1992) In Research on Motivation in Education; Vol. 3. Goals and Cognitions, (13-44). San Diego, CA: Academic Press.

[73] Schunk Dale, H. (1990): Introduction to the special section on motivation and efficacity. Journal of Educational Psychology, $82,(3-6)$.

[74] Sigmund Freud (1875-1939): Freudian Psychoanalytic Theory of Personality https://courses.lumenlearning.com/boundlesspsychology/chapter/psychodynamic-perspectives-onpersonality/

[75] Slavin, Robert E. (1980a): "Effects of Individual Learning Expectations on Student Achievement." Journal of Educational Psychology 72, (520-524).

[76] Slavin, Robert E. (1980b): Effects of student teams and peer tutoring on academic achievement and time on-task. Journal of Experimental Education, 48, (252-257).

[77] Slavin, R. E. \& Karweit N. L. (1985): "Effects of WholeClass, Ability-Grouped, and Individualized Instruction on Mathematics Achievement." American Educational Research Journal 22: 351-367.

[78] Stephen, J. M. (1966): The psychology of classroom learning, New York: Holt Rinehart and Winston, Inc.

[79] Stevens, R. J., Slavin, R. E., Farnish \& A. M. Madden, N. A. (1988): Effect of cooperative learning and direct instruction in reading comprehension strategies on main ideas identification. Paper presented at the meeting of the American Research Association, New Orleans, LA.

[80] Thorkildson, T. A. \& Nicholls, J. G. (1998): Fifth grader's achievement orientations and beliefs: individual and classroom differences. Journal of Educational Psychology, 90, 179-201.

[81] Wallace, M. et al (2013): Mindfulness training and reductions in teacher stress and burnout: Results from two randomized, waitlist-control field trials. Journal of Educational Psychology, 105: 3, (787-804). https://doi.org/10.1037/a0032093. 